\title{
Trauma, Mental Health, Coping, Resilience, and Post Traumatic Growth (PG)-Palestinian Experience
}

\author{
Abdel Aziz Mousa Thabet* \\ Consultant Psychiatrist at Child and Family Training and Counselling Center, Al Quds University, Palestine
}

Submission: May 03, 2017; Published: June 07, 2017

*Corresponding author: Abdel Aziz Mousa Thabet, M.B.Ch.B, DPM, DCAC, PhD , Emeritus Professor of Child and Adolescent Psychiatry-School of Public Health- Al Quds University-Palestine. Consultant Child and Adolescent Psychiatrist. Affiliated Professor with Center for Refugee StudiesYork University.

President of Child and Adolescent Psychiatry sector at the Arab Federal Psychiatrists- Chief Editor of Arab Journal of Child and Adolescent Psychiatry. Member of the Executive Committee of Arab Federal Psychiatrists, Tel 009782834292; Mobile 00970599604400;

Email: abdelazizt@hotmail.com, abdelazizt@hotmail.com.

\section{Introduction}

\section{Coping}

Based on Lazarus and Folkman's [1] model, coping refers to the behavioral and cognitive efforts one uses to manage the internal and external demands of a stressful situation. Coping can be classified as being either problem-focused or emotionfocused in nature. Lazarus \& Folkman's [1] stress-coping theory, in which the individual assesses both the relevance of the environmental stressor (i.e. what he or she has at stake in the encounter) and his or her coping options before deciding on coping strategies to deal with the stressor. This theory's general emphasis on "coping," however, could be expanded to encompass "development" or "growth." There are three dimensions are most commonly used to categorize coping strategies:

A. Problem-focused and emotion-focused coping.

B. Primary and secondary control coping.

C. Engagement and disengagement coping (also referred to as approach versus avoidance coping) [2].

D. Problem-focused coping involves activities that focus on directly changing elements of the stressful situation.

E. Emotion-focused coping involves activities that focus more on modifying one's internal reactions resulting from the stressful situation.

Coping strategies includes a broad diversity of thoughts and behaviors used to manage the demands of a taxing situation [1]. Multiple research groups have attempted to organize coping strategies (and styles) into different categories.

The approach/avoidance construct, as the label implies, indicates whether the individual makes attempts to change the situation or distance him- or herself from the stressor as a way to reduce negative outcomes.
Coping strategies implemented immediately following trauma exposure, and in response to post traumatic stress. Avoidance as a sort of coping, such as behavioral or emotional avoidance, have been associated with increased psychological distress among interpersonal violence PTSD populations [3]. Avoidance behaviors could lead to withdrawal from support networks and reduced opportunities for positive experience, thereby compounding negative affect and reduced emotional experiencing. Approach-oriented coping strategies, such as active coping, planning, and support seeking, have been generally deemed adaptive following exposure to stress [4].

Social support is a variable that has been considered as both a means of coping and a resource contributing to the availability of other forms of coping [5]. The different ways of conceptualizing the role of social support in coping, and the relative lack of studies that examine reciprocal relationships between coping factors, has created some confusion about what roles social support may play in helping women deal with domestic violence.

\section{Resilience}

Over the decades, definitions of resilience in sciences concerned with child and family systems have become more dynamic, multilevel, and process oriented in focus, reflecting a broad theoretical shift toward a relational developmental systems framework in life course human developmental science and related fields [6].

Resilience and post traumatic growth (PG) theory and research are rooted in the philosophical stance that emphasizes the consideration of positive (salutogenic), rather than pathological or negative factors in trauma research [7]. Distinctions should also be made between posttraumatic growth and the concepts of resilience, hardiness, optimism, and sense 
of coherence. All these concepts describe certain personal characteristics that allow people to manage adversity well.

Resilience is usually considered to be an ability to go on with life after hardship and adversity, or to continue living a purposeful life after experiencing hardship and adversity. Smith defined resilience as a process that leads to "strength awareness", but psychological resilience may be operationally defined as strength awareness itself-that is, the belief that one can persevere or accomplish goal-relevant tasks across varied challenges and adverse situations.

Given this growing interest in scalable definitions, resilience can be defined broadly as "the capacity of a dynamic system to adapt successfully to disturbances that threaten its function, viability, or development" [8]. This definition of resilience could apply to an individual, family, computer system, economy, or ecosystem, among other systems. The capacity of any given system to adapt to challenges depends on the function of many interacting, changing systems. The resilience of children and their families are intertwined and also linked to supports and systems beyond the family in community, culture, and the physical environment.

Child resilience investigators have long recognized that resilience is inferred from judgments about risk (discussed further below) and adaptive function or development [9]; What are the criteria or standards by which we identify whether a person, a family, or any other system is adapting well? Issues in defining positive child development, adaptation, competence, or success have received considerable attention in child resilience science. What are the criteria or standards by which we identify whether a person, a family, or any other system is adapting well? One major approach to the criteria for judging adaptation is positive, focused on age-related expectations for behavior and achievement defined by communities and societies, often termed "developmental tasks" [10]. A second approach for judging adaptation, defined by low levels or absence of symptoms or disorder, stems from the initial focus on children at risk for psychopathology in the history of child resilience science. This negative approach has been criticized theoretically [11] and also from a common-sense perspective.

\section{Family Resilience}

What does it mean for a family system to be doing well or fulflling its functions effectively? Walsh [12], the concept of family resilience shifted attention from family as a resource or protective system for the individual members of a family to the function of the family unit as a whole, studied in terms of family adaptation or maladaptation in the context of adversity and the family processes that sustain family resilience. McCubbin [13] described the desired outcomes of family resilience in terms of success in fulfilling important expected functions of the family. These tasks included functions such as providing a sense of belonging and meaning, affording economic support, educating and socializing family members, and protecting vulnerable members of the family [14]. The effectiveness or success of a family would then be judged according to these expectations. Again, the criteria were multidimensional.

\section{Post Traumatic Growth}

In contrast, post traumatic growth refers to a change in people that goes beyond an ability to resist and not be damaged by highly stressful circumstances. Calhoun defined post traumatic growth as "positive change that an individual experiences as a result of the struggle with a traumatic event". In contrast to the construct of resilience, in which the individual returns to baseline functioning following highly stressful or traumatic experience, post traumatic growth is characterized by post-event adaptation that exceeds pre-event levels. Despite this interesting body of literature, there is still limited evidence on how living in areas of war and political conflict impact on university students, and which types of personal growth they may develop in response in relation to resilience. The aim of this paper to review papers conducted in Gaza Strip targeting children and adults using coping, resilience, and PTG.

\section{Method}

The author reviewed all his previous work in the area using the available data.

\section{Results}

As shown in the Table 1, 2 \& 3 [26]. 
Table 1: Studies of effect of coping and resilience in Palestinian.

\begin{tabular}{|c|c|c|c|}
\hline Authors and Year & Sample & Measures & Findings \\
\hline $\begin{array}{l}\text { Abdel Aziz Mousa } \\
\text { Thabet [15] }\end{array}$ & $\begin{array}{c}\text { A study of } 97 \text { male adolescents aged 15-19 } \\
\text { years, and attending a vocational training } \\
\text { center based in the } \\
\text { Gaza Strip. }\end{array}$ & $\begin{array}{l}\text { Adolescents completed } \\
\text { the Child Maltreatment } \\
\text { Schedule and the Ways of } \\
\text { Coping Scale (WAYS). The } \\
\text { Strengths and Difficulties } \\
\text { Questionnaire (SDQ) was } \\
\text { completed by adolescents } \\
\text { and by their teachers. }\end{array}$ & $\begin{array}{l}\text { Mental health } \\
\text { Overall, } 8.3 \% \text { of young people reported likely } \\
\text { clinical problems, contrasted to } 13.5 \% \text { as } \\
\text { reported by teachers. These findings indicate } \\
\text { that the likely rates of total psychiatric } \\
\text { morbidity were relatively low. } \\
\text { Specific self-rated scores included } \\
\text { hyperactivity (5.3\%) and emotional problems } \\
\text { (4.1\%). Teacher-rated scores indicated } \\
\text { conduct problems (3.1\%), hyperactivity } \\
\text { (3.1\%), and emotional problems ( } 3.1 \% \text { ). } \\
\text { Coping } \\
\text { High rates of emotional and physical } \\
\text { maltreatment. Reliance on emotion- focused } \\
\text { or avoidant coping strategies was associated } \\
\text { with exposure to maltreatment. Use of } \\
\text { maladaptive coping also predicted emotional } \\
\text { difficulties in the respondents. } \\
\text { The coping strategies most commonly used in } \\
\text { stressful situations were "acceptance of faith } \\
\text { in God" (used almost all the time by } 79.4 \% \text { ), } \\
\text { and "searching for information on how to get } \\
\text { help" (used almost all the time by } 60.8 \% \text { ). The } \\
\text { least commonly used strategies were "eating, } \\
\text { drinking, or smoking" (never used by 79.4\%), } \\
\text { "being angry towards people who are not } \\
\text { the cause of the problem" (not at all used by } \\
\text { 59.8\%), and "take risks to get what I want" } \\
\text { (not at all used by } 40.2 \% \text { ). } \\
\text { The emotional problems subscale in self-rated } \\
\text { SDQ scores were strongly predicted by the use } \\
\text { of "trying to feel better by eating, drinking, } \\
\text { smoking, using drugs or medication" Teacher- } \\
\text { rated total sDQ scores were best predicted by } \\
\text { two coping strategies blaming oneself and } \\
\text { refusing to believe what happened. }\end{array}$ \\
\hline $\begin{array}{l}\text { Abdel Aziz Mousa } \\
\text { Thabet [16] }\end{array}$ & $\begin{array}{c}250 \text { children from the martyrs families in } \\
\text { Gaza strip governorates by representative } \\
\text { sample of } 112 \text { males and } 138 \text { females aged } \\
10-16 \text { years old. }\end{array}$ & $\begin{array}{c}\text { Gaza Traumatic event } \\
\text { checklist A COPE (Carver, } \\
\text { 1989) }\end{array}$ & $\begin{array}{l}\text { The most used coping strategy was religious } \\
\text { coping ( } 86.4 \%) \text {, but the lowest coping } \\
\text { strategy was substance use (30.3\%). } \\
\text { There were significant differences between } \\
\text { the means of positive reinterpretation and } \\
\text { growth, mental disengagement, focus on } \\
\text { and venting of emotion, use of instrumental } \\
\text { social support, active coping, religious coping, } \\
\text { restraint, and planning according to trauma } \\
\text { levels in favor of severe traumatic events. }\end{array}$ \\
\hline
\end{tabular}




\begin{tabular}{|c|c|c|c|}
\hline $\begin{array}{c}\text { Thabet Abdelaziz } \\
{[17]}\end{array}$ & $\begin{array}{l}\text { Participants consisted of } 424 \text { children and } \\
\text { adolescents aged between 8-16 years, who } \\
\text { were randomly selected from } 32 \text { schools in } \\
\text { Gaza and the West Bank. }\end{array}$ & $\begin{array}{l}\text { Traumatic Event Checklist, } \\
\text { the Impact of Event Scale, } \\
\text { and the Adolescent Coping } \\
\text { Orientation for Problems } \\
\text { Experiences }\end{array}$ & $\begin{array}{l}\text { Children experienced an average of } 13.7 \\
\text { traumatic events. The most common } \\
\text { traumatic events were, witnessing demolition } \\
\text { of a friend's home }(92.4 \%) \text { and hearing killing } \\
\text { of a close relative }(84.4 \%) \text {. The frequency } \\
\text { of IES scores above the established cut-off } \\
\text { score (likely PTSD) was } 21.2 \% \text {. There was } \\
\text { significant association between exposure } \\
\text { to traumatic events and PTSD symptoms. } \\
\text { Exposure to trauma was moderated by } \\
\text { seeking social and spiritual support in } \\
\text { predicting PTSD symptoms }\end{array}$ \\
\hline Thabet AA [18] & $\begin{array}{l}\text { The study sample consisted of } 358 \\
\text { adolescents aged } 15 \text { to } 18 \text { years old age. } \\
\text { The mean age was } 16.7 \text { years. One hundred } \\
\text { fifty eight were boys ( } 44.1 \% \text { ) and } 200 \text { were } \\
\text { girls }(55.9 \%) \text {. }\end{array}$ & $\begin{array}{l}\text { Gaza Traumatic Events } \\
\text { Checklist, Spence Children's } \\
\text { Anxiety Scale, Post } \\
\text { Traumatic Stress Disorder } \\
\text { according to DSM-IV scale, } \\
\text { and Adolescent-Coping } \\
\text { Orientation for Problem } \\
\text { experiences Scale. }\end{array}$ & $\begin{array}{l}\text { The study showed that, the mean traumatic } \\
\text { events reported by adolescents was } 13.34 \text {. } \\
\text { The traumatic experiences reported by the } \\
\text { adolescents in order were: } 90.8 \% \text { watched } \\
\text { mutilated bodies on TV, } 88.5 \% \text { heard shelling } \\
\text { of the area by heavy artillery, } 86.6 \% \text { saw the } \\
\text { signs of shelling on the ground, and } 86.0 \% \\
\text { heard the sonic sounds of the jetfighters. } \\
\text { The results showed the mean total anxiety } \\
\text { was } 41.18 \text {, obsessive compulsive subscale } \\
\text { was } 8.90 \text {, generalized anxiety subscale was } \\
\text { 4.46, social phobia was } 6.99 \text {, separation } \\
\text { anxiety was 6.16, physical injury fears was } \\
5.48, \text { and panic/Agoraphobia was 5.4. The } \\
\text { results showed that girls had more anxiety } \\
\text { problems than boys including all anxiety } \\
\text { subscales. Regard PTSD, the study showed } \\
\text { that } 11.8 \% \text { of adolescents reported no PTSD, } \\
24.2 \% \text { reported less than two clusters of } \\
\text { symptoms, and } 34.31 \% \text { reported symptoms } \\
\text { meeting criteria for partial PTSD, while } 29.8 \% \\
\text { reported symptoms meeting criteria for full } \\
\text { PTSD according to DSM-IV-TR. The results } \\
\text { showed that girls reported more PTSD than } \\
\text { boys. Palestinian adolescents mainly cope } \\
\text { commonly by developing social support, } \\
\text { investing in close friends, and/or engaging } \\
\text { in demanding activities. The study showed } \\
\text { that adolescents experienced traumatic } \\
\text { experiences developed less social support and } \\
\text { positively asked more professional support } \\
\text { as coping strategies. Adolescents with PTSD } \\
\text { had coping by ventilating feelings, developing } \\
\text { social support, avoiding problems, and } \\
\text { Adolescents with less PTSD had looking more } \\
\text { for solving his family problems. Adolescents } \\
\text { with anxiety were ventilating feelings, } \\
\text { developing social support, and engaging in } \\
\text { demanding activities. Adolescents with less } \\
\text { anxiety were seeking more spiritual support. }\end{array}$ \\
\hline
\end{tabular}




\begin{tabular}{|c|c|c|c|}
\hline Thabet AA [19] & 449 children of 7 to 18 years & $\begin{array}{c}\text { Gaza Traumatic Events } \\
\text { Checklist-20 items-War } \\
\text { on Gaza, UCLA PTSD scale, } \\
\text { Birleson Depression Scale, } \\
\text { Child Revised Manifest } \\
\text { Anxiety Scale, and Kidcope } \\
\text { for children. }\end{array}$ & $\begin{array}{l}\text { Children reported many traumatic events } \\
\text { (mean = 4). One third ( } 32.5 \% \text { ) had partial } \\
\text { and } 12.4 \% \text { had full criteria of PTSD. Children } \\
\text { living in families with low family monthly } \\
\text { income reported more emotional problems. } \\
\text { There was significant association between } \\
\text { exposure to traumatic events and developing } \\
\text { PTSD. The rates of significant anxiety and } \\
\text { depressive symptoms were } 20.5 \% \text { and } 22.3 \% \\
\text { respectively. Girls reported significantly } \\
\text { more depressive symptoms than boys. } \\
\text { Children commonly used the following } \\
\text { coping strategies: wishful thinking, problem- } \\
\text { solving, emotional regulation, and distraction. } \\
\text { Trauma was negatively correlated with social } \\
\text { support and wishful thinking, and positively } \\
\text { correlated with self-criticism. Lack of social } \\
\text { support and wishful thinking predicted all } \\
\text { three types of mental health problems, while } \\
\text { social withdrawal specifically predicted } \\
\text { depression. }\end{array}$ \\
\hline Juma A [20] & $\begin{array}{c}\text { The sample consisted of randomly } \\
\text { selected } 399 \text { university students from } \\
\text { main four universities in Gaza Strip (Al- } \\
\text { Aqsa, Al-Azhar, Al-Quds Open and Islamic } \\
\text { University) }\end{array}$ & $\begin{array}{l}\text { Stressful Situations } \\
\text { Checklist, Hamilton } \\
\text { Anxiety Rating Scale, Beck } \\
\text { Depression Inventory and } \\
\text { Carver Brief Coping Scale. }\end{array}$ & $\begin{array}{l}\text { This study showed the most frequent } \\
\text { stressors were (92\%) said prices are sharply } \\
\text { increased due to closure, (83.5) said their } \\
\text { study was affected so much due to cut-off } \\
\text { of electricity and shortage of gas. The study } \\
\text { results showed that mean stressors in males } \\
\text { was } 12.38 \text { and was } 10.33 \text { in females. There } \\
\text { were statistically significant differences in } \\
\text { stress toward males. } \\
\text { The study showed } 9.5 \% \text { of males and } 12 \% \\
\text { of females had severe depression. No gender } \\
\text { differences. Also, } 10.3 \% \text { of males and } 13.8 \% \text { of } \\
\text { females had anxiety. No statistically significant } \\
\text { differences in anxiety according to gender. } \\
\text { The study showed that there were statistically } \\
\text { significant positive relationship between total } \\
\text { stress due to siege and depression symptoms } \\
\text { and anxiety. } \\
\text { The most frequent coping strategies were } \\
\text { (78.2\%) find comfort in religious beliefs, } \\
\text { (71.4\%) think about what steps to take } \\
\text { (67.7\%) learn to live with situation. There } \\
\text { were statistically significant negative } \\
\text { relationship between total score of stress due } \\
\text { to siege and total coping strategies. }\end{array}$ \\
\hline
\end{tabular}




\begin{tabular}{|c|c|c|c|}
\hline Thabet AA [21] & $\begin{array}{l}\text { The sample consisted of } 449 \text { subjects. The } \\
\text { age ranged from } 21 \text { to } 60 \text { years with mean } \\
\text { age } 41.5 \text { years. }\end{array}$ & $\begin{array}{l}\text { Hopkins Symptoms } \\
\text { Checklist Scale and Family- } \\
\text { Oriented Coping Scale } \\
\text { support scale }\end{array}$ & $\begin{array}{l}\text { The study showed than } 52.6 \% \text { had anxiety, } \\
\text { and } 50.6 \% \text { had depression. Females scored } \\
\text { more anxiety and depression than males. } \\
\text { Mental health symptoms were more in family } \\
\text { with family monthly income } \$ 300 \text { and less, } \\
\text { and in families with } 8 \text { and more children. The } \\
\text { results showed that mean total family coping } \\
\text { strategy was } 107.28 \text {. Males were significantly } \\
\text { reported more coping strategies, including } \\
\text { acquiring social support, reframing, seeking } \\
\text { spiritual support, and mobilizing family to } \\
\text { acquire and accept help. Total HSCL score was } \\
\text { negatively correlated with total family coping } \\
\text { strategies, acquiring social support, reframing, } \\
\text { seeking spiritual support, and positive } \\
\text { appraisal. }\end{array}$ \\
\hline $\begin{array}{l}\text { Abdel Aziz Mousa } \\
\text { Thabet [22] }\end{array}$ & $\begin{array}{c}\text { A sample of } 449 \text { adults, the age ranged } \\
\text { from } 21 \text { to } 60 \text { years with mean age } 41.5 \\
(S D=8.6), 193 \text { were males (53.9\%) and } \\
181 \text { were females } 46.1 \% .\end{array}$ & $\begin{array}{l}\text { Gaza Traumatic Events } \\
\text { Checklist-20 items, War on } \\
\text { Gaza), PTSD, and Ways of } \\
\text { Coping Scale. }\end{array}$ & $\begin{array}{l}\text { Mean traumatic events experienced } 5.4 \\
\text { traumatic events and } 42 \% \text { reported full } \\
\text { criteria of PTSD. Mean coping scores was } \\
\text { 107.28, acquiring social support mean was } \\
\text { 29.59, reframing mean was } 31.22 \text {, seeking } \\
\text { spiritual support mean was } 15.93 \text {, mobilizing } \\
\text { family to acquire and accept help mean was } \\
\text { 14.14, and positive appraisal mean was } 13.89 \text {. } \\
\text { Traumatic events were significantly negatively } \\
\text { correlated to other coping strategies such as } \\
\text { reframing and mobilizing family to acquire } \\
\text { and accept help. } \\
\text { Participants with no PTSD scored more } \\
\text { coping, acquiring social support, reframing, } \\
\text { and seeking spiritual support, positive } \\
\text { appraisal. While, there was no significant } \\
\text { differences in mobilizing family to acquire and } \\
\text { accept help with PTSD. }\end{array}$ \\
\hline
\end{tabular}

Table 2: Posttraumatic growth (PTG).

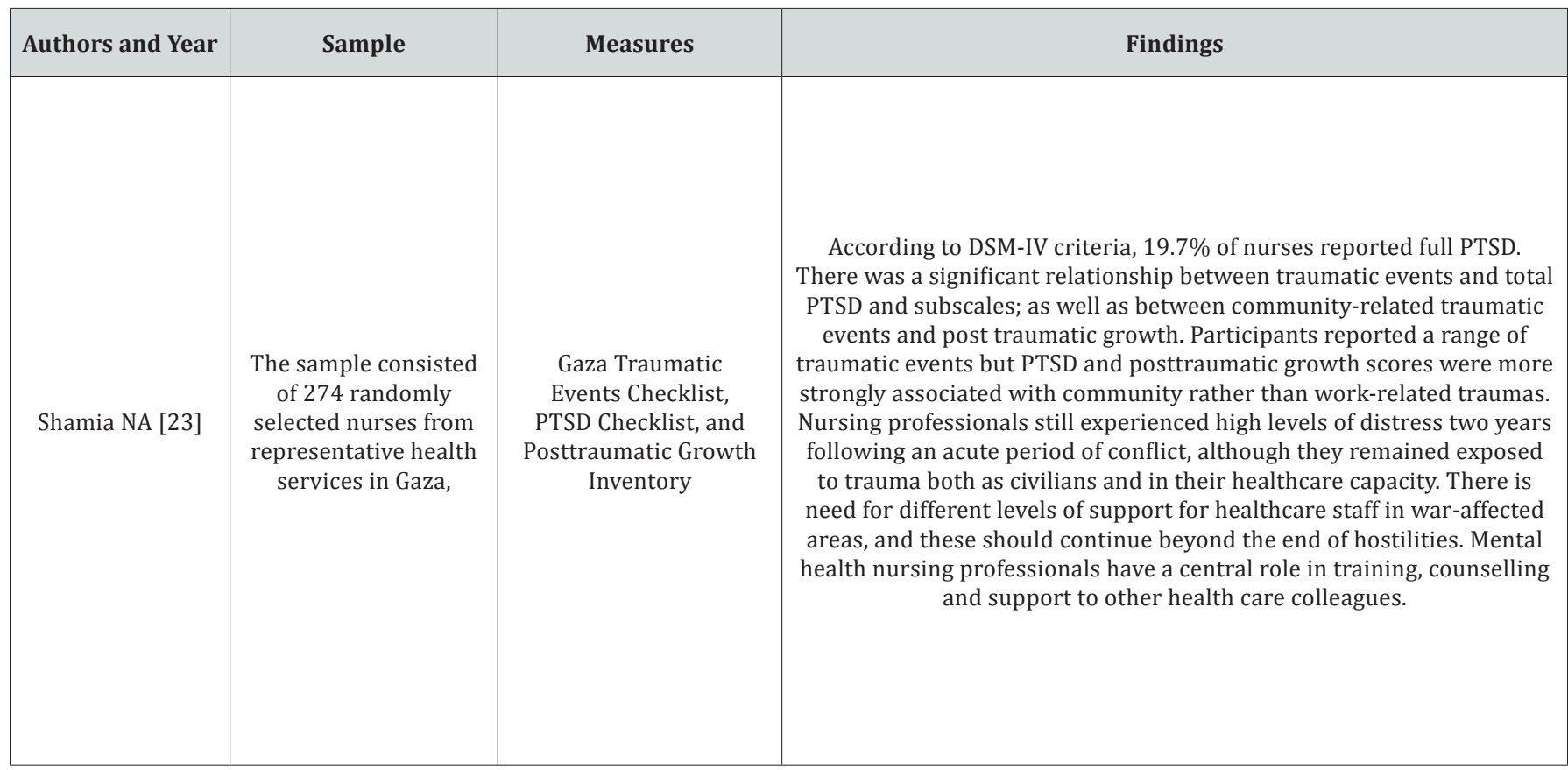




\begin{tabular}{|c|c|c|c|}
\hline Thabet AA [24] & $\begin{array}{l}\text { The sample consisted } \\
\text { of } 381 \text { randomly } \\
\text { selected student's } \\
\text { representing the four } \\
\text { major universities in } \\
\text { Gaza Strip. }\end{array}$ & $\begin{array}{l}\text { Gaza Traumatic Events } \\
\text { Checklist, Resilience } \\
\text { scale, and Posttraumatic } \\
\text { Growth Inventory }\end{array}$ & $\begin{array}{l}\text { Participants reported a range of traumatic events; the highest } \\
\text { frequencies reported traumatic events were watching mutilated bodies } \\
\text { in TV ( } 94.5 \%) \text {, hearing shelling of the area by artillery ( } 92.4 \%) \text {, hearing } \\
\text { the loud voice of drone's motors ( } 87.4 \%) \text {, and inhalation of bad smells } \\
\text { due to bombardment ( }(78.7 \%) \text {. While, the least common traumatic } \\
\text { experiences were: hearing killing of a friend (11\%), and being arrested } \\
\text { during the land incursion witnessing ( } 18.9 \%) \text {. Mean traumatic events } \\
\text { reported by universities students were } 10 \text { events. While, } 6 \% \text { reported } \\
\text { mild, } 36 \% \text { moderate and } 58 \% \text { severe traumatic events. Male students } \\
\text { reported more traumatic events than females. Mean post traumatic } \\
\text { growth was } 67.34 \text {, appreciation of life was } 7.17 \text {, new possibilities } \\
\text { were } 12.25 \text {, the personal strength was } 10.62 \text {, and spiritual change was } \\
\text { 6.82. Males had significantly more post traumatic growth than females } \\
\text { and females had significantly more spiritual changes than males. For } \\
\text { resilience, mean resilience was } 55 \text {, personal competence was } 22.32 \text {, } \\
\text { positive acceptance was } 13.49 \text {, trust in one's instincts was } 16.30 \text {, } \\
\text { control was } 7.96 \text {, and spiritual influences were } 7.31 . T h e r e \text { were gender } \\
\text { differences on resilience subscale. Males had significantly more positive } \\
\text { acceptance than females, trust in others, control, spiritual influences, } \\
\text { and females had significantly more spiritual changes than males. } \\
\text { Traumatic events had no association with post traumatic growth and } \\
\text { total resilience. However, resilience was positively correlated with post } \\
\text { traumatic growth. }\end{array}$ \\
\hline
\end{tabular}

Table 3: Resilience

\begin{tabular}{|c|c|c|c|}
\hline $\begin{array}{l}\text { Authors } \\
\text { and Year }\end{array}$ & Sample & Measures & Findings \\
\hline $\begin{array}{c}\text { Abadsa } \\
{[25]}\end{array}$ & $\begin{array}{c}\text { A sample of } 255 \\
\text { participants } \\
\text { was selected, } \\
120 \text { were } \\
\text { males (47.1\%) } \\
\text { and } 135 \\
\text { were females } \\
(52.9 \%) . \text { The } \\
\text { age ranged from } \\
18-67 \text { years } \\
\text { with mean age } \\
\text { was }(\mathrm{M}=31.77+ \\
14.84) .\end{array}$ & $\begin{array}{c}\text { Arabic version of } \\
\text { Symptoms Checklist- } \\
\text { 90-Revised, and Arabic } \\
\text { version of Resilience } \\
\text { Attitude Scale. }\end{array}$ & $\begin{array}{l}\text { Mean resilience was 60.84, Males had more resilience than females, more } \\
\text { committed, more able to control, and challenging than females. People living in } \\
\text { north Gaza had less resilient and less challenging than people living in Gaza or } \\
\text { Khan Younis. Psychological problems, obsessive compulsive, depression, anxiety, } \\
\text { phobic anxiety, paranoid, and psychosis were correlated negatively with resilience. } \\
\text { Also, total psychological problems, sensitivity, and phobic anxiety were correlated } \\
\text { negatively with commitment. Sensitivity, anxiety and phobic anxiety were negatively } \\
\text { correlated with control. With total psychological problems, obsessive compulsive, } \\
\text { sensitivity, depression, anxiety, paranoid and psychosis were correlated negatively } \\
\text { with challenge. }\end{array}$ \\
\hline $\begin{array}{c}\text { Thabet AA } \\
\text { [19] }\end{array}$ & $\begin{array}{l}\text { The participants } \\
\text { were } 386 \\
\text { Palestinian } \\
\text { children and } \\
\text { adolescents } \\
\text { from Gaza (age } \\
13.41+2.96 \\
52.07 \% \\
\text { boys and } \\
47.93 \% \text { girls) }\end{array}$ & $\begin{array}{c}\text { Gaza Traumatic } \\
\text { Events Checklist, Child } \\
\text { Depression and Anxiety } \\
\text { Scale, UCLA PTSD Index } \\
\text { for DSM-IV-Adolescent } \\
\text { Version, and Resilience } \\
\text { Attitude Scale. }\end{array}$ & $\begin{array}{c}\text { There were generally no gender differences in the exposure to traumatic events, as } \\
\text { all. Neither were } \\
\text { there gender differences in the mean number of traumatic events related to Israeli } \\
\text { military violence or Palestinian } \\
\text { factional fighting. According to the DSM-IV criterion, } 12.4 \% \text { of the children and } \\
\text { adolescents reported probable } \\
\text { PTSD, and } 22.37 \% \text { filled the two criteria partial PTSD, and } 26.7 \% \text { the one criteria } \\
\text { partial PTSD (re-experiencing or } \\
\text { PTSD. There were no significant } \\
\text { avoidance or hyper arousal). More than a third (38.4\% of the children did not have } \\
\text { differences between boys and girls in PTSD. For depression and anxiety, boys and } \\
\text { girls did not differ in the levels of PTSD, depressive and anxiety symptoms. Also only } \\
\text { one marginal gender difference was found concerning resilience characteristics: } \\
\text { girls reported more feelings of control than boys. The results revealed that } 25.0 \% \text { of } \\
\text { the participants } \\
\text { was classified as resilient indicating presence of high exposure to traumatic events } \\
\text { and absence of PTSD and } 22.2 \% \text { as traumatized, i.e., presence of both high exposure } \\
\text { to trauma and occurrence of PTSD. Of the children } 12.7 \% \text { were classified as } \\
\text { vulnerable, and } 40.1 \% \text { were spared of both high trauma and PTSD }\end{array}$ \\
\hline
\end{tabular}




\begin{tabular}{|c|c|c|c|}
\hline $\begin{array}{c}\text { Thabet AA } \\
{[23]}\end{array}$ & $\begin{array}{c}\text { A sample } \\
\text { consisted of } \\
502 \text { randomly } \\
\text { selected } \\
\text { subjects from } \\
5 \text { areas of the } \\
\text { Gaza Strip. Age } \\
\text { Mean }=42.49 \\
\text { (SD }=7.6)\end{array}$ & $\begin{array}{l}\text { Stressful Situations } \\
\text { due to Siege Scale, } \\
\text { Gaza Traumatic Events } \\
\text { Checklist, Brief Symptom } \\
\text { Checklist-BSI-19, World } \\
\text { Health Organization } \\
\text { Quality of Life, and } \\
\text { Resilience scale }\end{array}$ & $\begin{array}{l}\text { The most common stressful situations due siege were: feelings of being living } \\
\text { in a big prison cannot finish some construction and repair work in their house } \\
\text { due to shortage of cement and building materials, prices were sharply increased } \\
\text { in the last few years. Participants commonly reported traumatic events such as } \\
\text { hearing shelling of the area by artillery, hearing the sonic sounds of the jetfighters, } \\
\text { hearing the loud voice of drones, and watching mutilated bodies in TV. Males had } \\
\text { significantly experienced severe traumatic events than females. People live in cities } \\
\text { reported more traumatic events than those live in a village or a camp. As a reaction } \\
\text { to stress and trauma Palestinians participants reported anxiety symptoms such } \\
\text { as nervousness or shakiness inside, feeling tense or keyed up; while depression } \\
\text { symptoms reported were feeling sad, and weak in parts of their body. However, } \\
\text { feelings of worthlessness and thoughts of ending life were seldom. Females reported } \\
\text { less stress and trauma, but they showed anxiety and somatization symptoms than } \\
\text { males. Only } 12.5 \% \text { said that they evaluate their life as good, and } 27.1 \% \text { said they } \\
\text { enjoy their life. Better quality of life is an indicator of wellbeing; females had higher } \\
\text { level of quality of life. While, physical health activities of daily living were more in } \\
\text { males was. Palestinians used religious ways of coping with the stress and trauma, } \\
\text { and } 98 \% \text { said God is helping all the time, they were proud of their achievements, } \\
\text { and had strong sense of purpose in their life. } \\
\text { There were statistically significant positive relationship between stress due to } \\
\text { the siege and closure and traumatic events, psychological symptoms, depression, } \\
\text { somatization, and anxiety. However, there was statistically significant negative } \\
\text { relationship between total score of stress due to the siege and closure and the total } \\
\text { resilience factor and subscales, and quality of life. Total traumatic events were } \\
\text { positively correlated with psychological symptoms, depression, somatization, and } \\
\text { anxiety. }\end{array}$ \\
\hline $\begin{array}{l}\text { Abdel Aziz } \\
\text { Mousa } \\
\text { Thabet } \\
\text { [21] }\end{array}$ & $\begin{array}{l}\text { The study } \\
\text { sample } \\
\text { consisted of } \\
502 \text { randomly } \\
\text { selected } \\
\text { children from } \\
16 \text { districts of } \\
\text { the Gaza Strip. } \\
\text { Age ranged } \\
\text { from } 9 \text { to } 16 \\
\quad \text { years }\end{array}$ & $\begin{array}{l}\text { Gaza Traumatic Events } \\
\text { Checklist, Post traumatic } \\
\text { stress disorder scale, } \\
\text { Children's Revised } \\
\text { Manifest Anxiety Scale, } \\
\text { and Resilience Scale for } \\
\text { Adolescents. }\end{array}$ & $\begin{array}{l}\text { Children reported commonly traumatic events such as hearing the loud voice of } \\
\text { Drones }(98.8 \%) \text {, hearing shelling of the area by artillery }(98.6 \%) \text {, hearing the sonic } \\
\text { sounds of the jetfighters }(98.4 \%) \text {, and watching mutilated bodies of Palestinians } \\
\text { in TV ( } 98.2 \%) \text {. Mean traumatic events reported by children was } 7 \text { events. Boys } \\
\text { reported severe traumatic events than girls; traumatic events were reported in } \\
\text { children living in a city than in village and camp. } \\
\text { This study showed that } 35.9 \% \text { of children showed full criteria of PTSD. Post- } \\
\text { traumatic stress disorder and re-experiencing symptoms were more in girls. Also, } \\
\text { children coming from families with family income less than } \$ 300 \text { and living in city. } \\
\text { The children anxiety symptoms, } 30.9 \% \text { of children had anxiety disorder. No } \\
\text { differences in anxiety disorder between boys and girls. Anxiety was more in children } \\
\text { living in camps and family monthly income less than } \$ 300 \text {. } \\
\text { Palestinians children used different ways of coping with the stress and trauma, and } \\
\text { common resilience items were } 94.6 \% \text { said they were proud of their citizenship, } \\
92.4 \% \text { said they feel safe when they were with their caregivers, } 91.4 \% \text { said that } \\
\text { their spiritual (religious) beliefs were a source of strength for them, and } 91 \% \text { said } \\
\text { they were proud of their family background } \\
\text { Total resilience in children, personal skills, peer component, and social skills, } \\
\text { contextual components that facilitate a sense of belonging (Spiritual beliefs, culture, } \\
\text { and educational items) were more in of girls. Total resilience and contextual } \\
\text { components were more in children living in a camps and a village than in a city. } \\
\text { However, there were statistically significant differences in individual factors } \\
\text { (personal skills, peer component, and social skills) were more in children from } \\
\text { family monthly income } \$ 301-750 \text { than families with monthly income of } 300 \$ \text { and } \\
\text { less. Also, traumatic events were correlated positively with anxiety and PSTD and } \\
\text { negatively correlated with total resilience factor. }\end{array}$ \\
\hline $\begin{array}{l}\text { Abdel Aziz } \\
\text { Mousa } \\
\text { Thabet } \\
\text { [14] }\end{array}$ & $\begin{array}{l}\text { The sample } \\
\text { consisted of } \\
449 \text { children } \\
\text { selected } \\
\text { randomly } \\
\text { from the five } \\
\text { localities } \\
\text { of the Gaza } \\
\text { Strip. Children } \\
\text { completed } \\
\text { the School } \\
\text { Violence Scale, } \\
\text { and Resilience } \\
\text { Attitude Scale. }\end{array}$ & $\begin{array}{l}\text { Children completed the } \\
\text { School Violence Scale, } \\
\text { and Resilience Attitude } \\
\text { Scale }\end{array}$ & $\begin{array}{l}\text { The study showed that } 20.18 \% \text { of children reported school violence, } 23.5 \% \\
\text { reported physical violence, } 12.29 \% \text { verbal violence, } 28.76 \% \text { self- defense, } 14.12 \% \\
\text { violence toward things, and } 22.33 \% \text { reported attitude to violence. There were } \\
\text { statistically significant differences toward boys in total school violence and all } \\
\text { violence subscales. Total resilience mean was } 57.3(40 \%) \text {, challenge mean was } 17.3 \text {, } \\
\text { commitment mean was } 15.16 \text {, and control mean was } 21.4 \text {. The results showed } \\
\text { significant differences in total resilience, commitment, and control attributed } \\
\text { to gender for the favor of boys. The results showed that total violence was not } \\
\text { correlated with commitment. Physical violence and violence toward things were } \\
\text { positively correlated with commitment. While, verbal violence was predicting } \\
\text { negatively resilience. }\end{array}$ \\
\hline
\end{tabular}




\begin{tabular}{|c|c|c|c|}
\hline $\begin{array}{l}\text { Abdel Aziz } \\
\text { Mousa } \\
\text { Thabet } \\
\text { [21] }\end{array}$ & $\begin{array}{l}\text { the sample } \\
\text { consisted of } \\
\text { randomly } \\
\text { selected } 399 \\
\text { university } \\
\text { students } \\
\text { enrolled from } \\
\text { the main four } \\
\text { universities in } \\
\text { Gaza Strip (Al- } \\
\text { Aqsa, Al-Azhar, } \\
\text { Al-Quds Open } \\
\text { and Islamic } \\
\text { University) }\end{array}$ & $\begin{array}{l}\text { Gaza Traumatic Events } \\
\text { Checklist, the State- } \\
\text { Trait Anxiety Inventory, } \\
\text { and Connor-Davidson } \\
\text { Resilience Scale. }\end{array}$ & $\begin{array}{l}\text { The aims of this study were to identify the type of the traumatic experiences, to } \\
\text { find the type of resilience, anxiety trait and state occurrence, and to determine } \\
\text { the relationship between exposure to the traumatic experiences, resilience and } \\
\text { anxiety trait and state among university students. It is a descriptive analytical } \\
\text { study; the sample consisted of randomly selected } 399 \text { university students enrolled } \\
\text { from the main four universities in Gaza Strip (Al-Aqsa, Al-Azhar, Al-Quds Open } \\
\text { and Islamic University) at the second semester of the academic year } 2012-2013 \text {. } \\
\text { The researcher used five questionnaires; a predesigned Socio- demographic sheet, } \\
\text { Gaza Traumatic Events Checklist, the State-Trait Anxiety Inventory, and Connor- } \\
\text { Davidson Resilience Scale. This study showed that the most commonly reported } \\
\text { traumatic events were watching mutilated bodies on TV ( } 92.7 \% \text { ), witnessing the } \\
\text { shelling and destruction of another's home (47.37\%), witnessing firing by tanks } \\
\text { and heavy artillery at neighbors' homes ( } 47.12 \%) \text {, and being forced to move from } \\
\text { home to a safer place during the war ( } 42.86 \% \text { ). Mean total traumatic events was } \\
\text { 4.72. Anxiety trait mean was } 36.22 \text { and anxiety state mean was } 46.62 \text {. The most } \\
\text { common resilience concepts (most of the time/all the time) were: God can help } \\
\text { (91.7\%), things happen for a reason ( } 90.3 \% \text { ), and I am proud of my achievement } \\
\text { (85.2\%). Male students had significantly more total resilience, more personal } \\
\text { competence and more trust in one's instincts than females. The results showed } \\
\text { that there was a significant correlation between total traumatic events and anxiety } \\
\text { state and trait no correlations between anxiety traits. The results found that there } \\
\text { was no significant correlation between total traumatic events and total resilience, } \\
\text { but there was a positive significant correlation between total traumatic events and } \\
\text { trust in one's instincts, tolerance of negative affect and strengthening effects. On the } \\
\text { other hand, there was a significant correlation between total traumatic events and } \\
\text { spiritual domain. There was a significant correlation between anxiety state and total } \\
\text { resilience and its subscales except in spiritual dimension. }\end{array}$ \\
\hline
\end{tabular}

\section{References}

1. Lazarus RS, Folkman S (1984) Stress, Appraisal and Coping. Springer, USA, ISBN: 0-8261-4191-9.

2. Compas BE, Connor-Smith JK, Saltzman H, Thomsen AH, Wadsworth ME (2001) Coping with stress during childhood and adolescence: Progress, problems, and potential in theory and research. Psychol Bull 127(1): 87-127.

3. Littleton H, Horsley S, John S, Nelson DV (2007) Trauma coping strategies and psychological distress: A meta-analysis. J Trauma Stress 20(6): 977-988.

4. Folkman S, Moskowitz JT (2004) Coping: pitfalls and promise. Annu Rev Psychol 55: 745-774.

5. Aspinwall LG, Taylor SE (1997) A stitch in time: self-regulation and proactive coping. Psychol Bull 121(3): 417-436.

6. Zelazo PD (2013) Developmental psychology: A new synthesis. In: Zelazo PD (Ed.), The Oxford handbook of developmental psychology. Body and mind New York, USA, pp. 3-12.

7. Tedeschi R, Calhoun L (2004) Posttraumatic growth: Conceptual foundations and empirical evidence. Psychological Inquiry 15(1): $1-18$

8. Masten AS (2014) Global perspectives on resilience in children and youth. Child Dev 85(1): 6-20.

9. Luthar SS, Cicchetti D, Becker B (2000) The construct of resilience: A critical evaluation and guidelines for future work. Child Dev 71(3): 543-562.

10. Mc Cormick CM, Kuo SI, Masten AS (2011) Developmental tasks across the lifespan. In: Fingerman KL, Berg C, Antonucci TC, Smith J (Eds.) The handbook of lifespan development. New York, USA, pp. 117-140.

11. Kaplan HB (1999) Towards an understanding of resilience. In: Glanz MD, Johnson JL (Eds.), Resilience and development, USA, pp. 17-83.

12. Walsh F (2011) Family resilience: A collaborative approach in response to stressful life challenges. In: Southwick S, Charney D, Litz
B, Freedman M (Eds.), Resilience and mental health: Challenges across the life span. New York, USA, pp. 149-161.

13. McCubbin H, Patterson JM (1982) Family adaptation to crises. In: McCubbin H, Cauble A, Patterson J (Eds.), Family stress, coping, and social support. Springfield, IL, USA, pp. 26-47.

14. Patterson JM (2002) Integrating family resilience and family stress theory. Journal of Marriage and Family 64(2): 349-360.

15. Thabet AA, Abdulla T, Vostanis P (2013) Coping Strategies of Children and Adolescents Exposed to War Conflict. Arabpsynet E Journal 39(40): 289-296

16. Thabet AA, Vostanis P (2014) Impact of Trauma on Palestinian Children's and the Role of Coping Strategies. British Journal of Medicine \& Medical Research 5(3): 330-340.

17. Thabet AA, Tawahina AA, Punamäki RL, Vostanis P (2015) Prevalence and Mental Health Function of Resilience in Condition of Military Siege and Violence in a Palestinian Community Sample. Journal of Psychiatry 18: 274

18. Thabet AA, EL-Buhaisi O, Vostanis P (2014) Trauma, PTSD, Anxiety, and coping strategies among Palestinians adolescents exposed to War on Gaza. The Arab Journal of Psychiatry 25(1): 71-82.

19. Thabet AA, Thabet S (2015) Stress, Trauma, Psychological Problems, Quality of Life, and Resilience of Palestinian Families in the Gaza Strip. Journal Clinical Psychiatry 1(1): 11-15.

20. Juma A, Thabet AA (2015) Relationship between stressors due to siege of Gaza Strip on anxiety, depression and coping strategies among university students. Arab Journal of Psychiatry 26(1): 39-48.

21. Thabet AA, Tawahina AA, Punamäki R, Vostanis P (2015) Prevalence and Mental Health Function of Resilience in Condition of Military Siege and Violence in a Palestinian Community Sample. Journal of Psychiatry 18(3): 1-9.

22. Thabet AA, Thabet S (2015) Trauma, PTSD, Anxiety, and Resilience in Palestinian Children in the Gaza Strip. British Journal of Education, Society \& Behavioural Science 11(1): 1-13. 
23. Shamia NA, Thabet AA, Vostanis P (2015) Exposure to war traumatic experiences, post-traumatic stress disorder and post traumatic growth among nurses in Gaza. J Psychiatr Ment Health Nurs 22(10): 749-755.

24. Thabet AA, Elheloub MW, Vostanis P (2015) Exposure to war traumatic experiences, post traumatic growth and resilience among university students in Gaza. American Journal of Advanced Medical Sciences (AJAMS) 1(1): 1-8.

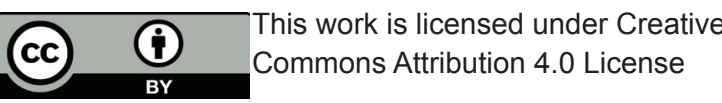

25. Abadsa A, Thabet AA (2012) Mental health problems among Palestinian University Students in the Gaza Strip. Arabpsynet E Journal 34-35: 227-235.

26. Masten AS (2006) Developmental psychopathology: Pathways to the future. International Journal of Behavioral Development 30(1): 47-54.

\section{Your next submission with Juniper Publishers will reach you the below assets}

- Quality Editorial service

- Swift Peer Review

- Reprints availability

- E-prints Service

- Manuscript Podcast for convenient understanding

- Global attainment for your research

- Manuscript accessibility in different formats

( Pdf, E-pub, Full Text, Audio)

- Unceasing customer service

Track the below URL for one-step submission https://juniperpublishers.com/online-submission.php 